\title{
Bio-energy generation in an affordable, single- chamber microbial fuel cell integrated with adsorption hybrid system: effects of temperature and comparison study
}

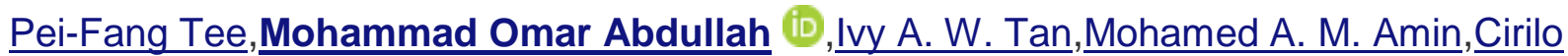 \\ Nolasco-Hipolito \& Kopli Bujang \\ Pages 1081-1088 | Received 20 Dec 2016, Accepted 12 Apr 2017, Accepted author version posted online: 18 Apr \\ 2017, Published online: 08 May 2017
}

\section{ABSTRACT}

A microbial fuel cell (MFC) integrated with adsorption system (MFC-AHS) is tested under various operating temperatures with palm oil mill effluent as the substrate. The optimum operating temperature for such system is found to be at $\sim 35^{\circ} \mathrm{C}$ with current, power density, internal resistance $\left(R_{\text {in }}\right)$, Coulombic efficiency (CE) and maximum chemical oxygen demand (COD) removal of $2.51 \pm 0.2 \mathrm{~mA}$, $74 \pm 6 \mathrm{~mW} \mathrm{~m}^{-3}, 25.4 \Omega, 10.65 \pm 0.5 \%$ and $93.57 \pm 1.2 \%$, respectively. Maximum current density increases linearly with temperature at a rate of $0.1772 \mathrm{~mA} \mathrm{~m}^{-2}$ ${ }^{\circ} \mathrm{C}^{-1}$, whereas maximum power density was in a polynomial function. The temperature coefficient $\left(Q_{10}\right)$ is found to be 1.20 between $15^{\circ} \mathrm{C}$ and $35^{\circ} \mathrm{C}$. Present studies have demonstrated better CE performance when compared to other MFC-AHSs. Generally, MFC-AHS has demonstrated higher COD removals when compared to standalone MFC regardless of operating temperatures.

Abbreviations: ACFF: activated carbon fiber felt; APHA: American Public Health Association; CE: Coulombic efficiency; COD: chemical oxygen demand; ECG: electrocardiogram; GAC: granular activated carbon; GFB: graphite fiber brush; MFC: microbial fuel cell; MFC-AHS: microbial fuel cell integrated with adsorption hybrid system; MFC-GG: microbial fuel cell integrated with graphite granules; POME: palm oil mill effluent; PTFE: polytetrafluoroethylene; SEM: scanning electron microscope

KEYWORDS: 